\title{
IMPROVEMENT OF PHONOLOGICAL SKILLS - IMPROVEMENT OF READING
}

\author{
Sarmite Tubele \\ University of Latvia, Latvia \\ Kristine Serova \\ University of Latvia, Latvia
}

\begin{abstract}
The article "Improvement of Phonological Skills - Improvement of Reading" underlines the importance of phonological awareness in the development of reading skills. Several studies show that reading is a very complex skill that involves cognitive processes, intellect and other variables, but the key factor for the development of good reading skills is a good level of phonological awareness.

Before the intervention a special material was created, which was systematically ordered according to the current level of each child's phonological awareness abilities. Children were evaluated before and after the intervention.

The aim of this research is to evaluate the possibility to develop good phonological analysis and synthesis skills for six to seven years old children with phonematic perception disorder.

The research methods used in the study are the analysis of scientific literature, the gathering of primary data with specially designed evaluation material, the analysis of gathered primary data, and the observation of child's performance during the training sessions.
\end{abstract}

Keywords: phonological awareness, reading skills, 6-8 years old children.

\section{Introduction}

Reading is a complicated process that involves perception, the knowledge of a language, memory, thinking and the intellect (Sternberg \& Sternberg, 2016). Throughout the history one can find different opinions of what it means to be a skilled reader, but as the need for reading grows together with the development of writing, one can say that reading is the ability to translate written symbols into phonemes. L. Vigotsky (Vigotskis, 2002) states that the phoneme is a particular sound that has a meaning and function in the language.

Before a child begins to read, he learns to speak and before he learns to speak, he grows up with caring people who communicate with him. Communication is a mutual interaction with the purpose to exchange information (Urževica, 2010). The prototype for communication is the speech of a human being (Vigotskis, 2002). The main purpose for writing is to communicate, so the ability to read is actually the ability to communicate. One can state it differently - reading 
and writing are the forms of speech together with talking and listening (Lūse, Miltiņa, \& Tūbele, 2012). While living in the modern society where one comes across written texts daily, it is hard to imagine that only part of all spoken languages has its written form (Sedivy, 2019) but there is no society without a language. Although every child is born with the ability to use the language, it only refers to the spoken one. The written form of the language has to be taught (Woolfolk, 2016; Bornstein \& Lamb, 2015; Tūbele, 2008). According to UNESCO gaining reading skills is one of the basic rights of a human being (Moterri \& Frandell, 2013). It is a basic skill for living in the modern society (Carreras, Armstrong, \& Danubeita, 2018) and it is the primary source of formal education (Chou, Cheng, \& Cheng, 2016). The level of individual literacy skills will determine the quality of life, educational possibilities and the level of selfesteem (Riley, 2001). In the era of information technology, literacy skills are even more important than ever before, because of the growing requirements not only to read, but to extract knowledge from large amounts of written information.

\section{Theoretical framework}

Summarising several authors (Carreras et al., 2018; Kaulina \& Tūbele, 2012; Lūse et al., 2012; Schleicher, 2019; Sternberg \& Sternberg, 2016; Tūbele, 2008; Tūbele \& Lūse, 2012; Woolfolk, 2016; Zmitričenoka, 2007) one can define the skill of reading as the ability to decode written symbols into the words of the language, the ability to understand these symbols, the reaction of speech to the written text, the receptive communication, the tool of critical thinking, decision making and knowledge acquisition. Reading skills are closely related to cognitive abilities.

The basic components of reading are cognitive processes, language comprehension, phonematic awareness, phoneme awareness, grapheme awareness and the technique of reading. Phonological awareness can be defined as the ability of a person to identify, distinguish and manipulate with the phonemes of language as well as the ability to notice the differences between phonematically similar words, words that are spoken incorrectly and the ability to produce rhymes (Berk, 2013; Charlesworth, 2014; Kaderavek, 2011; Sedivy, 2019; Tūbele, 2019; Tūbele \& Lūse, 2012; Tūbele, 2002; Wagner \& Torgesen, 1987). Thus, phonematic awareness consists of phonematic perceptions (knowledge about the phonemes of language, the ability to pronounce them and differentiate between them), phonematic analysis (the ability and skill to distinguish separate phonemes and sequence them in the correct order) and synthesis (the ability and skill to merge phonemes into syllables and larger units in order to compose meaningful words of language). Phonological awareness is closely related with phonematic hearing and phonematic notion that lays source 
of phonological analysis. Phonematic hearing or notion can be defined as the ability to hear single phonemes, recognize and distinguish them from each other and form larger units of language (Lūse et al., 2012; Ptičkina, 1997).

Several studies (Lopez-Escribano, Ivanova, \& Shtereva, 2018) show the importance of other aspects, rather than phonological awareness only and are taking into consideration rapid automatized naming. During the research (Stappen \& Reybroeck, 2018) where rapid automatized naming was evaluated separately from phonological awareness, the researchers discovered that the first one is rather an important indicator of the access speed of lexicon than the skill that could be trained. There are scientists (Fisher \& Frey, 2014) which state the importance of vocabulary knowledge as important aspect of reading. Although it is true that one can understand written text well enough if 95 percent of words are known (Sternberg \& Sternberg, 2016), good vocabulary at age five in itself does not guarantee good reading skills at age seven (Gillon, 2017).

Many researches have shown strong relation between phonological awareness and reading skills. G. Gillon (Gillon, 2017) names 16 researches where a positive link was found between delayed development of phonological awareness and low reading skills. Other longitudinal researches state that good phonological awareness in early childhood results in good reading skills later (Kaderavek, 2011; Kenner, Terry, Friehling, \& Namy, 2017; Tūbele \& Lūse, 2012; Tūbele, 2019). Although phonological processing develops unconsciously (Kenner et al., 2017) it is not only the result of cognitive processes maturity (Goswami, 2007). Phonological processing develops strongly when one learns to read (Karule, 1997; Wagner \& Torgesen, 1987). Persons without literacy skills are unable to distinguish phonemes from spoken words (Lightfoot, Cole \& Cole, 2009). Once the skill of phonological analysis has been gained, it becomes the foundation of person's language perception, i.e., one does not separate words between different language forms (Goswami, 2007), he can distinguish every phoneme and order them in the right sequence. Several researches have proved positive impact from phonological awareness training (Gillon, 2017; Goswami \& Bryant, 2016; Guanze, 2010; Lightfoot et al., 2009; Tūbele, 2019). So, one can say that even if there are delays in phonological awareness and because of that the ability to learn reading is delayed, there is a possibility to train both.

In order to understand whether there are any delays in phonological awareness, one must characterize normal development. Several studies have analysed phonological awareness development in different age groups. Depending on age group, language, performed training and the complexity of test task, some common similarities where found. The summary of different researches (Gillon, 2010; Goswami \& Bryant, 2016; Irbe \& Lindenberga, 2015; Kaderavek, 2011; Karule, 1997; Kenner et al., 2017; Lightfoot et al., 2009; 
Tūbele, 2019; Tūbele \& Lūse, 2012) of the development of phonological awareness can be seen in the table (Table 1).

Table 1 Development of phonological awareness skills

\begin{tabular}{|c|c|}
\hline Age & $\begin{array}{l}\text { Phonological awareness skills } \\
\end{array}$ \\
\hline 3 years & $\begin{array}{l}\text { Can perform simple rhymes and nursery rhymes; } \\
\text { Can distinguish two equal names called in word sequence; } \\
\text { Can distinguish phonematically spare word in three words sequence; } \\
\text { Knows how to make compound words if they consist of direct words; } \\
\text { May perform simple phonematic synthesis from sounds with pictures. }\end{array}$ \\
\hline $\begin{array}{l}3-4 \\
\text { years }\end{array}$ & $\begin{array}{l}\text { Knows how to make compound words that are not obvious; } \\
\text { Can select words that rhymes; } \\
\text { Comes up with rhyme words; } \\
\text { Can divide into syllables phonematically simple words; } \\
\text { Knows how to pronounce all phonemes from mother tongue (with some exceptions); } \\
\text { Protests on errors of pronunciation. }\end{array}$ \\
\hline $\begin{array}{l}4-5 \\
\text { years }\end{array}$ & $\begin{array}{l}\text { Can divide compound words into their components; } \\
\text { Can perform rhymes that are not obvious; } \\
\text { Can divide into syllables phonematically not so simple words; } \\
\text { Comes up with new names that has similar syllable structure or words that has the same } \\
\text { syllable in common; } \\
\text { May perform phonematic synthesis from different syllables; } \\
\text { Can name onset and rime (first sound and ending sounds of syllable); } \\
\text { Can name words without onset; } \\
\text { Can distinguish words with the same onset or rime. }\end{array}$ \\
\hline $\begin{array}{l}5-6 \\
\text { years }\end{array}$ & $\begin{array}{l}\text { Can divide any compound words into their components; } \\
\text { Can distinguish between all sounds in phonematically simple words, and put all phonemes } \\
\text { in right sequence; } \\
\text { Can distinguish words with the same sounds at the same sequential position; } \\
\text { With help of picture can call missing phoneme from any position; } \\
\text { Knows how to make syllable from given two or three sounds. }\end{array}$ \\
\hline $\begin{array}{l}6-7 \\
\text { years }\end{array}$ & $\begin{array}{l}\text { Can distinguish between all sounds in phonematically not so simple words (words with } \\
2 \text { consonant blends at the beginning or middle of word), and put all phonemes in right } \\
\text { sequence; } \\
\text { Comes up with phonological neighbours or relatives to word; } \\
\text { Likes crosswords and sound games with rules; } \\
\text { Can perform phonological synthesis from three to four sounds that makes one syllable; } \\
\text { Comes up with words that are made from separate phonemes without consonant blends; } \\
\text { With help of picture can call more than one missing phoneme at any given position. One } \\
\text { missing phoneme can be determined without help of picture. }\end{array}$ \\
\hline $\begin{array}{l}7-8 \\
\text { years }\end{array}$ & $\begin{array}{l}\text { Can manipulate with any phoneme in known words even with complex consonant blends; } \\
\text { Can name all missing phonemes in any position without help of picture, understands } \\
\text { complex consonant blends at the end of word; } \\
\text { One has developed metalinguistics of language. }\end{array}$ \\
\hline
\end{tabular}

All the abilities are sequentially related to one another, i.e., skills that a child can perform at the age of three will lay the foundation for skills at the age of four etc. Several researches (Gillon, 2017; Lightfoot et al., 2009) have emphasized that 
the ability to distinguish phonemes at the age of five to six will strongly predict the ability to decode sound and letter at the age of seven and reading skills at the age of nine. Consequently, phonological awareness is crucial in the development of reading skills.

\section{Methodology}

For the purpose of this research authors gathered primary data with specially designed evaluation material. Children were evaluated before and after the training. In the evaluation process phonematic analysis and synthesis and simple non-word reading skills were detected. During the first and last evaluation different control words were used. The last evaluation included words that were not used at the first evaluation and during the training.

According to table 1and after primary data analysis from the first evaluation, for the purposes of research the authors summarized suggestions found in literature (Anthony \& Francis, 2005; Guangze, 2010; Gillon, 2017; Irbe \& Lindenberga, 2015; Karule, 1997; Lightfoot et al., 2009; Ptičkina, 1997; Tūbele \& Lūse, 2012) and created a system for phonological awareness training tasks. The training material was created for research purposes and it was divided into three major parts and subparts as described in the table (Table 2).

Table 2 Training area and designed materials

\begin{tabular}{|c|c|}
\hline Training area & Designed materials \\
\hline $\begin{array}{l}\text { Training for } \\
\text { phonological } \\
\text { notion }\end{array}$ & $\begin{array}{l}\text { Logopedic dictation; } \\
\text { Listening to a word in a word row; } \\
\text { Listening to a particular sound in a sound row; } \\
\text { Repeat syllables; } \\
\text { Name a word with a specific sound. }\end{array}$ \\
\hline $\begin{array}{l}\text { Training for } \\
\text { phonological } \\
\text { analysis }\end{array}$ & $\begin{array}{l}\text { Distinguish words; } \\
\text { Distinguish syllables; } \\
\text { Distinguish onsets, rimes; } \\
\text { Distinguish first, last sound; } \\
\text { Distinguish any sound; } \\
\text { Distinguish any sound in correct sequence. }\end{array}$ \\
\hline $\begin{array}{l}\text { Training for } \\
\text { phonological } \\
\text { synthesis }\end{array}$ & $\begin{array}{l}\text { To make compound words; } \\
\text { Sounds: first - two sounds in syllable, second - three sounds in syllable where } \\
\text { consonant exchanges vowel, third - three and more sounds in syllable in any } \\
\text { combination; } \\
\text { Syllables: first - two open two letter syllables in two syllable words, second - } \\
\text { open and closed two letter syllables in different combination in two or three } \\
\text { syllable words, third - open and closed two or more letter syllables in different } \\
\text { combination. }\end{array}$ \\
\hline
\end{tabular}


All three training areas are closely related and can be trained simultaneously but one should follow the level of difficulty through training.

During training following suggestions were taken into consideration. A. Karule (Karule, 1997) suggests practicing out loud first and only then using one's inner voice. A. Ptichkina (Ptičkina, 1997) suggests starting the analysis of word phonemes with long vowels and consonant sounds that can be stretched or extended during speech, then short vowels and diphthongs and then all other phonemes. In order to distinguish separate phonemes, A. Karule (Karule, 1997) and A. Ptichkina (Ptičkina, 1997) recommends use of sound cards in three colours - red for vowels, blue for voiced consonants and black for non voiced consonants. To guarantee that the child can see the actual number of sounds or letters research authors used boxes or stripes that symbolise sounds or corresponding letters.

\section{Research results}

The research took place in two preschool and primary school groups. There were 33 children participating in the training. All children had phonological perception disorder. All children received training once a week for 30 to $40 \mathrm{~min}$ during the period of four months. During every training session the authors were at the position of speech therapist and observer. Every training session contained all three training areas. In every session feedback from children was gathered. Since the children were already familiar with letters, they were used as support for distinguishing individual phonemes. The results of evaluation can be seen in the following figures (Fig. 1 and Fig. 2) both figures represents percentual amount if errors at eliciting sounds before and after intervention.

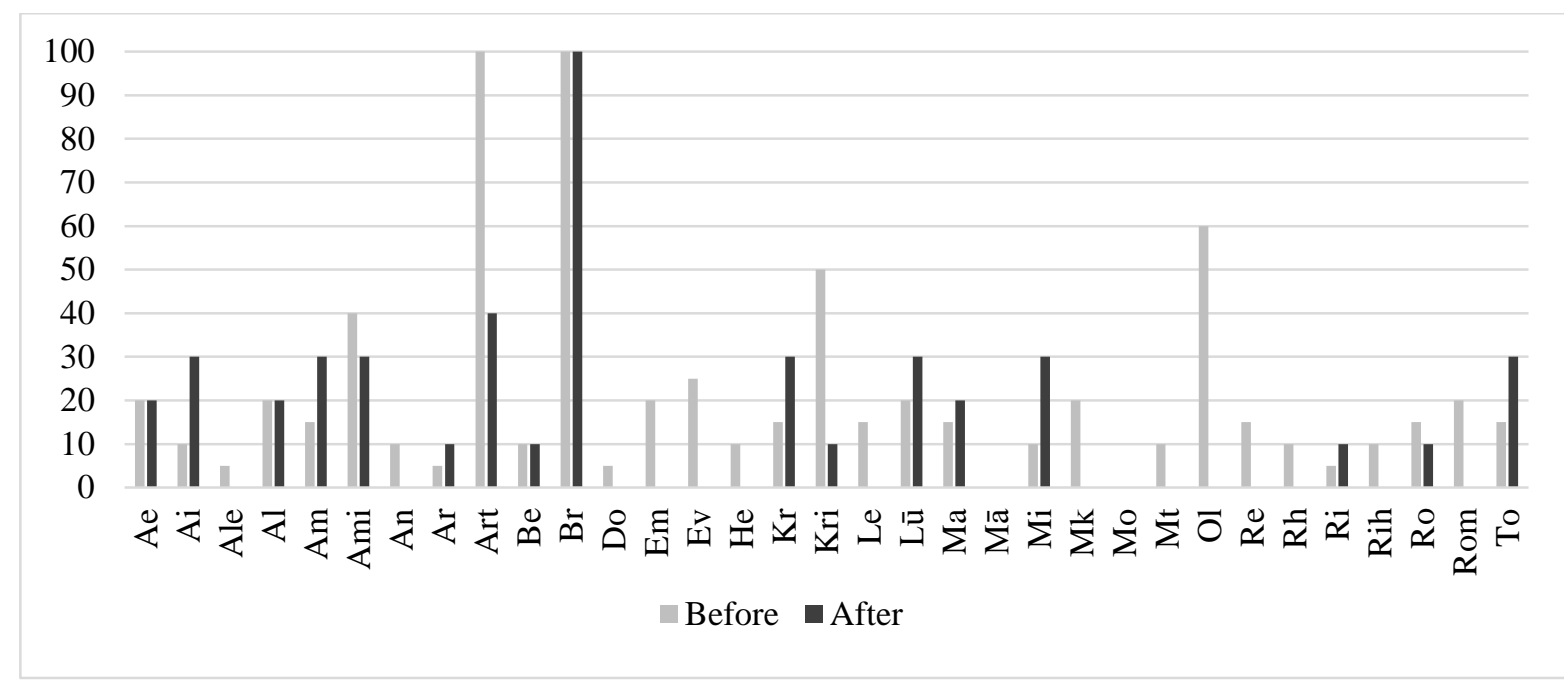

Figure 1 Percentual amount of errors at eliciting first sound before and after intervention 
As one can see in figure (Fig. 1), overall level of phonematic ability has improved. Children that showed lower results at the last evaluation actually made constant mistakes in words with long vowels, i. e., intervention tasks were not enough to correct the level of phonematic perception disorder as such.

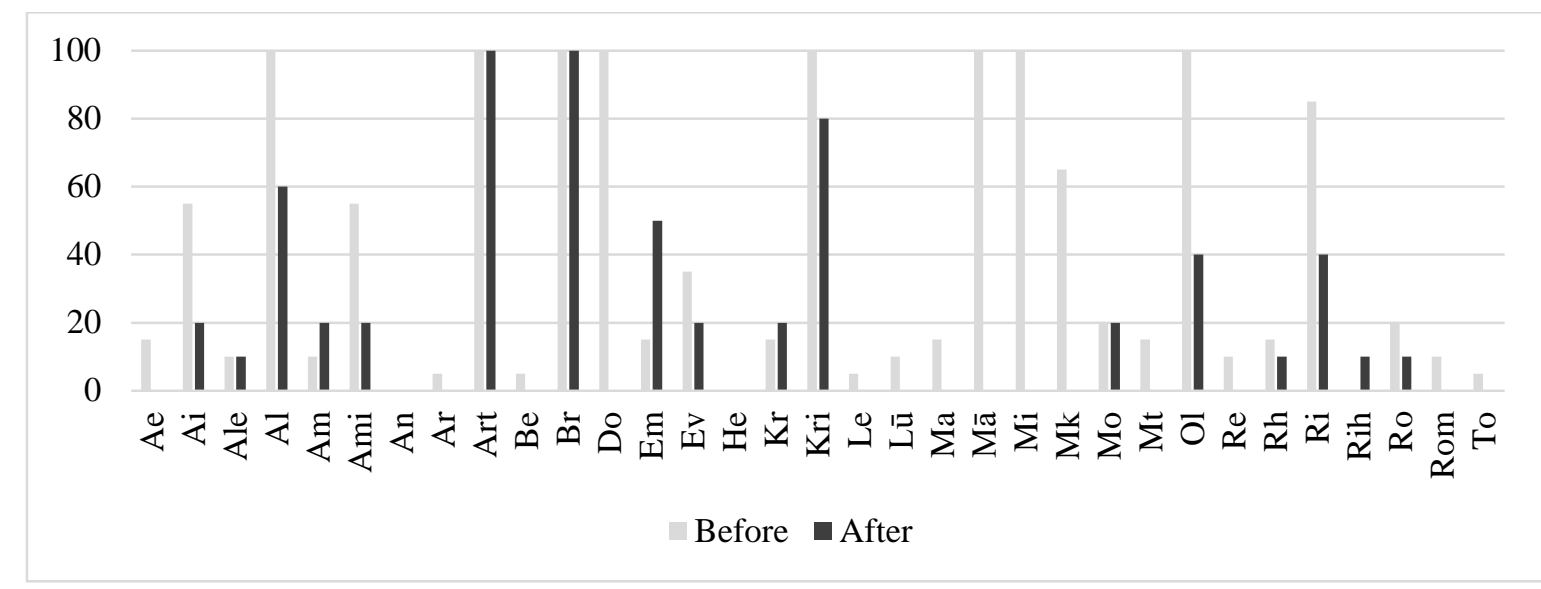

Figure 2 Percentual amount of errors at eliciting last sound before and after intervention

As one can see in figure (Fig. 2 ), overall level of phonematic ability has improved. Child "Br" didn't show any improvement during the last evaluation. He was lacking improvement in other subjects outside study as well. Child "Art" has improved his phonematic analysis ability - during the first evaluation he could not call any first or last sound, he called the first syllable, during the last evaluation he could name a rime of words last syllable but still could not elicit one last phoneme.

It was not possible to evaluate non-word reading speed and correctness for all children, but for those who participated in this evaluation, the reading speed and correctness improved from around 1 min for 12 nonwords with 6 errors to approximately 48 seconds and 4 errors for the same amount of non-words.

\section{Conclusions and discussion}

Although phonological awareness is biologically determined as other cognitive processes, it is possible to improve phonematic analysis and synthesis results by carefully selecting appropriate intervention material and methods. One can discuss the level of improvement for children that develop typically and children with developmental delays or disorders. As it was stated in theoretical framework - phonological awareness can be improved. This statement was proved to be true for the majority of the selected children. The children, who did not succeed in phonological analysis skill, did not show improvement in other 
areas outside study either. These children should receive detailed evaluation of their cognitive capabilities.

During the research one of the largest problems was the lack of appropriate evaluation methods, therefore the creation and approbation of these methods is going to be the main task of the next research.

\section{References}

Anthony, J.L., \& Francis, D.J. (2005). Development of Phonological Awareness. Current Directions in Psychological Science, 14(5) DOI: 10.1111/j.0963-7214.2005.00376.x

Berk, L.E. (2013). Child development. 9th edition. India: Pearson.

Bornstein, M.H., \& Lamb, M.E. (2015). Developmental science an advanced textbook. NY: Psychology press.

Carreras, M., Armstrong, B.C., \& Danubeita, J.A. (2018). Reading, Stevens' Handbook of Experimental Psychology and Cognitive Neuroscience, 4th edition, Vol. 3 Language and Thought. USA: Wiley.

Charlesworth, R. (2014). Understanding child development. 9th edition. ASV: Wadsworth.

Chou, M., Cheng, J., \& Cheng, Y. (2016). Operating Classroom Aesthetic Reading Environment to Raise Children's Reading Motivation. Universal Journal of Educational Research, 4(1), 81-97. DOI: 10.13189/ujer.2016.040111

Fisher, D., \& Frey, N. (2014). Content Area Vocabulary Learning. The Reading Teacher, 68(8), 594-599. doi: 10.1002/trtr.1258

Gillon, G.T. (2017). Phonological Awareness. Second Edition: From Research to Practice. USA: Guilford Publications.

Goswami, U., \& Bryant, P. (2016). Phonological Skills and Learning to Read. USA: Routledge Taylor \& Francis group.

Goswami, U. (2007). Cognitive development critical concepts in psychology. USA: Routledge Taylor \& Francis group.

Guangze, L. (2010). Phonological Processing Abilities and Reading Competence: Theory and Evidence. USA: Peter Lang.

Irbe, A., \& Lindenberga, S. (2015). Bērns runāt mācās gimenē [Child learns to speak in the family]. Rīga: RaKa.

Kaderavek, J.N. (2011). Language Disorders in Children: Fundamental Concepts of Assessment and Intervention. USA: Pearson.

Karule, A. (1997). Ābeces mācību metodika [Methods of teaching Alphabet]. Rīga: Zvaigzne ABC.

Kauliņa, A., \& Tūbele, S. (2012). Lasǐšanas traucējumi [Reading Disorders]. Rīga: RaKa.

Kenner, B.B., Terry, N.P., Friehling, A.H., \& Namy, L.L. (2017). Phonemic awareness development in 2.5- and 3.5-year-old children: an examination of emergent, receptive, knowledge and skills. Reading and Writing, 30(7), 1575-1594. DOI: 10.1007/s11145017-9738-0

Lightfoot, C., Cole, M., \& Cole, S. R. (2009). The Development of Children 6th edition. USA: Worth Publishers.

Lopez-Escribano, C., Ivanova, A., \& Shtereva, K. (2018). Rapid Automatized Naming (RAN) and Vocabulary are significant predictors of reading in consisting orthographies: comparison of reading acquisition procedures in Bulgarian and Spanish. Electronic 
SOCIETY. INTEGRATION. EDUCATION

Proceedings of the International Scientific Conference. Volume IV, May $22^{\text {th }}-23^{\text {th }}$, 2020. 157-165

Journal of Research in Educational Psychology, 16(44), 147-173. DOI: 10.25115/ejrep.v16i44.1941

Lūse, J., Miltiņa, I., \& Tūbele, S. (2012). Logopēdijas terminu skaidrojošā vārdnīca [Glossary of speech therapy terms]. Rīga: RaKa.

Moterri, G.A.S., \& Frandell, T. (2013). Literacy from a Right to Education Perspective. UNESCO. Retrieved from https://unesdoc.unesco.org/ark:/48223/pf0000221427

Ptičkina, Ā. (1997). Kā mācissim bèrnus lasìt un rakstīt [How to teach children to read and write]. Rīga: Zvaigzne ABC.

Riley, J. (2001). The National Literacy Strategy: success with literacy for all? Curriculum Journal, 12(1), 29-58. DOI: 10.1080/09585170122654

Schleicher, A. (2019). PISA 2018 Insights and Implementations. Paris: EOCD Publications.

Sedivy, J. (2019). Language in Mind: An Introduction to Psycholinguistics. Great Britain: Oxford University press.

Stappen, C.V., \& Reybroeck, M.V. (2018). Phonological Awareness and Rapid Automatized Naming Are Independent Phonological Competencies With Specific Impacts on Word Reading and Spelling: An Intervention Study. Front Psychology, 9(320) DOI: $10.3389 /$ fpsyg.2018.00320

Sternberg, R.J., \& Sternberg, K. (2016). Cognitive Psychology. 7th edition, USA: Change Learning.

Tūbele, S., \& Lūse, J. (2012). Ja skolēns raksta nepareizi [If a child writes incorrectly...]. Rīga: RaKa.

Tūbele, S. (2002). Skolēna runas attīstības vērtēšana [Evaluation of student's speech development]. Rīga: RaKa.

Tūbele, S. (2008). Disleksija vai lasī̌sanas traucējumi [Dyslexia or Reading Disabilities]. Rīga: RaKa.

Tūbele, S. (2019). Valodas traucējumu novērtēšana [Evaluation of Language Disorders]. Rīga: RaKa.

Urževica, S. (2010). Rokasgrāmata latviešu valodā [Handbook in Latvian]. Rīga: Zvaigzne ABC.

Vigotskis, L. (2002). Domāšana un runa [Thinking and Speaking]. Rīga: Madonas poligrāfists.

Wagner, R.K., \& Torgesen, J.K. (1987). The Nature of Phonological Processing and Its Causal Role in the Acquisition of Reading Skills. Psychological Bulletin, 101(2), 192-212. DOI:10.1037/0033-2909.101.2.192

Woolfolk, A. (2016). Educational Psychology. 13th edition. USA: Pearson.

Zmitričenoka, V. (2007). Lasīšanas traucējumi un to novēršana 5 - 6 gadus veciem bērniem ar VSNA III pakāpē logopēdiskajā grupā [Reading disabilities and prevention in 5-6 years old children with DLD in logopedic group]. From: Inovācijas skolotāja logopēda darbībā 3. Izdevums [Innovations in the activity of speech therapists. 3rd edition]. Rēzekne: RTA. 146-245. 